\title{
SPECIFICATION OF LOGISTIC CHAIN SUSTAINABILITY: ENVIRONMENTAL, SOCIAL AND ECONOMIC ISSUES
}

\author{
HADDACH Abdelhay \\ Abdelmalek Essaâdi University, Faculty of Sciences and Techniques, Tangier, Morocco. \\ Research Team: Materials, Environment and Sustainable Development \\ haddachabdelhay@gmail.com
}

\begin{abstract}
KEY WORDS: Supply Chain, Sustainable Development, Global Performance, Management, Company, Issues; Economic, Environmental, Social, Corporate Social Responsibility.
\end{abstract}

\begin{abstract}
:
This paper is based on the analysis of ninety-six articles published over twenty-one years, between 1991 and 2012 concerning integration of sustainable development objectives into supply chain management. Disciplinary and geographical origin of authors shows a growing interest in the integration of sustainable development in supply chain management for scientific world, but maturity of this subject remains limited and the most of these studies still exploratory. A more in-depth study of these works therefore seems relevant. Analysis of these works highlights several economic, environmental and social concepts which concern the diffusion of sustainable development in daily activities of supply chain like financial performance, productivity, environmental management systems and Human rights. This work will look at the main sustainable development issues which characterize global performance (integration of economic, environmental and social performances) of supply chain and impact of sustainable practices on performances of this chain, as they appear in studied articles.
\end{abstract}

\section{INTRODUCTION}

Financial dimension has long been the single determinant of supply chain performance. This performance was based on the achievement of profitability requested by the shareholders to perpetuate supply chain and its profit. Now, and for decades, supply chain performance has shifted from financial representation to more holistic approaches, including environmental and social dimensions. Currently, sustainability of supply chain no longer depends only on the financial aspect of their activities, but also on the way in which it is managed. Supply chains responsibility is widening to include other stakeholders (trade unions, NGOs, ...). Thus, and in these circumstances, there appears the notion of "global performance". To evaluate impacts of their supply chains on economic, environmental and social issues and to analyse how these impacts interact with each other, companies are obliged to develop appropriate approaches to sustainable development.

Traditional performance measurement issues, such as costs, are not enough for supply chains to have a clear view of environmental and social consequences of their management practices. In addition, assessing created value and progress made through sustainable development approach is an extremely delicate question. Challenge for supply chains is to be able to appreciate these created value and progress by measuring sustainable performances.

Most of currently available approaches are based on environmental dimension of sustainable development, in particular reverse logistics issues, while impacts of supply chains management practices are very numerous and extremely complex, integrating the three dimensions of sustainable development (economic, environmental and social) (Haddach et al., 2017). Thus, the question can be formulated as follows: How can we characterize supply chain global performance?

\section{GLOBAL PERFORMANCE APPROACH}

Financial performance is no longer enough to reflect global performance of supply chain. During the 20th century, performance widened to consider company social/societal responsibility vis-a-vis its stakeholders. Global performance is emerging in Europe with the emergence of sustainable development, but its origins lie in older concepts such as societal responsibility (a concept first appeared in United States and then in Europe).

If American vision of social responsibility is limited to philanthropic actions unrelated to company economic activities, European approach tends to consider that philanthropic actions do not fall within the scope of CSR (Corporate Social Responsibility) and actions that fall under it are assessed in relation to usual activities of company (Capron and QuairelLanoizelee, 2007). In Europe, company job and actions under societal responsibility constitute the same set. European Commission defines precisely the European approach to CSR:" CSR is a concept that refers to voluntary integration by companies of social and environmental concerns into their business activities and their relations with their stakeholders" (COM, 2001, p.8). This Commission describes companies as socially responsible if they go beyond the minimum legal requirements and obligations imposed by collective agreements to meet societal needs. CSR allows companies of all sizes to contribute to reconciling economic, social and environmental ambitions in cooperation with their partners (COM, 2006).

European approach to CSR makes sustainable development notion more operational for companies. If sustainable development, a macroeconomic concept, challenges companies in their goals, in the design of their organizations, by providing them with the principles which determine their economic activities, societal responsibility is the way companies respond to societal challenges at the microeconomic level (Capron and Quairel-Lanoizelee, 2007).

Sustainable development principle is based on the balance of its three dimensions to prevent the pursuit of one objective to the detriment of the other two. It is in this context that the notion of global performance has emerged.

Important contributions in this area date back, in 1997, to the working group of the Commissariat General of the Plan (Capron and Quairel-Lanoizelee, 2005, p.64), in which global performance is defined "as a multidimensional aim (or goal), economic, social and societal, financial and environmental, which concerns both companies and human societies, both employees and citizens ". In the current 
managerial literature, "global performance is mobilized to evaluate implementation by companies of sustainable development concept" (Capron and Quairel-Lanoizelee, 2005). This global performance of companies is defined as "the aggregation of economic, social and environmental performances"(Baret, 2006, p.2); (Reynaud, 2003, p.10) or is formed "by the meeting of financial, social and societal performances" (Germain and Trébucq, 2004).

Global performance of companies refers to "a holistic conception seeking to designate a performances integration in a synthetic approach ... this integration can imply a coherence between the three dimensions with causality models linking different factors from different dimensions" (Capron and Quairel-Lanoizelee, 2005, p.7). Thus, "evaluation systems currently used by companies do not allow a balanced integration of traditional economic and financial dimensions to environmental and social dimensions and to cover a wider scope of impacts" (Capron and Quairel-Lanoizelee, 2005).

\section{LITERATURE ANALYSIS}

Considering sustainable development in supply chain management, being new, we analyzed ninety-six contributions to provide a comprehensive analysis framework. Different contributions are classified according to the three dimensions of sustainable development (Table 1). Based on the classification, we identify global performance issues most studied in literature as well as measurement methods and indicators most commonly used to integrate global performance in supply chain management. So:

1. Many diverse sustainable issues are presented in scientific literature;

2. Economic and environmental dimensions are more represented than social dimension;

3. There is little interest in social dimension;

4. A low number of contributions and standards encompass the three dimensions simultaneously;

5. Total number of issues per contribution is between one and thirty-two. Indeed, we find that there is a very wide range according to contributions;

6. Number of issues per dimension is between one and thirteen for economic dimension, between one and twenty-two for environmental dimension and between one and fourteen for social dimension.

\begin{tabular}{|c|c|c|c|c|}
\hline Reference & Economic issues & Environmental issues & Social issues & Total issues \\
\hline Azzone et al., 1991 & 5 & & & 5 \\
\hline Lynch and Cross, 1991 & 10 & & & 10 \\
\hline Fitzgerald et al., 1992 & 6 & & & 6 \\
\hline Bradley 1996 & 4 & & & 4 \\
\hline Noci, 1997 & 3 & 6 & & 9 \\
\hline Ranganathan, 1998 & & 4 & 4 & 8 \\
\hline Giannikos, 1998 & 1 & 2 & & 3 \\
\hline Carter and Ellram, 1998 & & 1 & & 1 \\
\hline Nema and Gupta, 1999 & 1 & 1 & & 2 \\
\hline Halberg, 1999 & & 6 & & 6 \\
\hline Azapagic and Perdan 2000 & 1 & 17 & 14 & 32 \\
\hline Jash, 2000 & & 19 & & 19 \\
\hline Lamberton, 2000 & & 6 & & 6 \\
\hline Luo et al., 2001 & 2 & 2 & & 4 \\
\hline Gunasekaran et al., 2001 & 4 & & & 4 \\
\hline Jung et al., 2001 & & 5 & 3 & 8 \\
\hline Olsthoorn et al., 2001 & 2 & 3 & & 5 \\
\hline Veleva and Ellenbecker, 2001 & & 3 & 3 & 6 \\
\hline Carter and Jennings, 2002 & & & 4 & 4 \\
\hline Warhurst, 2002 & & 4 & & 4 \\
\hline Krikke and al., 2003 & 1 & 2 & & 3 \\
\hline Barbiroli and Raggi, 2003 & 3 & 9 & & 12 \\
\hline Krajnc and Glavic, 2003 & 2 & 7 & 2 & 11 \\
\hline Färe et al., 2004 & & 4 & & 4 \\
\hline Khan et al., 2004 & 3 & 12 & 4 & 19 \\
\hline C. M. Tam et al., 2004 & & 11 & & 11 \\
\hline Zhu et Sarkis, 2004 & 3 & 7 & & 10 \\
\hline Dotoli et al., 2005 & 4 & 2 & & 6 \\
\hline Hugo et al., 2005 & 1 & 1 & & 2 \\
\hline Hugo and Pistikopoulos, 2005 & 1 & 4 & 1 & 6 \\
\hline Gauthier, 2005 & & 6 & 3 & 9 \\
\hline
\end{tabular}

Table 1 (1) . Literature classification according to sustainable development issues 


\begin{tabular}{|c|c|c|c|c|}
\hline $\begin{array}{r}\text { Reference } \\
\end{array}$ & Economic issues & Environmental issues & Social issues & Total issues \\
\hline Jung et al., 2001 & & 5 & 3 & 8 \\
\hline Olsthoorn et al., 2001 & 2 & 3 & & 5 \\
\hline Labuschagne et al., 2005 & 4 & 4 & 4 & 12 \\
\hline Krajnc and Glavic, 2005a & 4 & 22 & 3 & 29 \\
\hline Krajnc and Glavic, 2005b & 5 & 7 & 2 & 14 \\
\hline Dotoli et al., 2006 & 2 & 2 & & 4 \\
\hline Nagurney et al., 2006 & 1 & 1 & & 2 \\
\hline Darnall et al., 2006 & & 8 & & 8 \\
\hline Kainuma and Tawara, 2006 & 3 & 4 & 1 & 8 \\
\hline Maxime et al., 2006 & & 5 & & 5 \\
\hline Michelsen et al., 2006 & & 9 & & 9 \\
\hline Rao et al., 2006 & & 5 & 1 & 6 \\
\hline Ferreti et al., 2007 & 1 & 1 & & 2 \\
\hline Hermann et al., 2007 & & 5 & & 5 \\
\hline Matos and J. Hall, 2007 & 13 & 6 & 7 & 26 \\
\hline Zhu et al., $2007 \mathrm{a}$ & 8 & 5 & & 13 \\
\hline Zhu et al., 2007b & 8 & 5 & & 13 \\
\hline Pati et al., 2008 & 2 & 2 & & 4 \\
\hline Pourmohammadi et al., 2008 & 1 & 2 & & 3 \\
\hline Quariguasi Frota Neto et al., 2008 & 1 & 3 & & 4 \\
\hline Castka and Balzarova, 2008 & & & 7 & 7 \\
\hline Henri and Journeault, 2008 & & 12 & & 12 \\
\hline Herva et al., 2008 & & 6 & & 6 \\
\hline Hutchins and Sutherland, 2008 & & & 4 & 4 \\
\hline O'Connor and Spangenberg, 2008 & 3 & 4 & 6 & 13 \\
\hline Vachon and Klassen, 2008 & 8 & & & 8 \\
\hline Bojarski et al., 2009 & 1 & 4 & 1 & 6 \\
\hline $\begin{array}{l}\text { Guillén Gosálbez and Grossman, } \\
2009\end{array}$ & 1 & 4 & 1 & 6 \\
\hline Mele et al., 2009 & 1 & 1 & & 2 \\
\hline de Benedetto and Klemes, 2009 & & 5 & 1 & 6 \\
\hline Nawrocka and Parker, 2009 & & 7 & & 7 \\
\hline Santos and Gonçalves, 2009 & 1 & 2 & & 3 \\
\hline Tseng et al., 2009 & 1 & 2 & 3 & 6 \\
\hline Nagurney and Nagurney, 2010 & 1 & 1 & & 2 \\
\hline Bouzembrak et al., 2010 & 1 & 1 & & 2 \\
\hline Fonseca et al., 2010 & 1 & 1 & & 2 \\
\hline $\begin{array}{l}\text { Guillén Gosálbez and Grossman, } \\
2010\end{array}$ & 1 & 4 & 1 & 6 \\
\hline Subramanian et al., 2010 & 1 & 2 & & 3 \\
\hline Corsano et al., 2011 & 1 & 2 & & 3 \\
\hline Pinto-Varela et al., 2011 & 1 & 3 & 1 & 5 \\
\hline Pozo et al., 2012 & 1 & 4 & 1 & 6 \\
\hline Wang et al., 2011 & 1 & 1 & & 2 \\
\hline You et al., 2011 & 1 & 1 & 1 & 3 \\
\hline You and Wang, 2011 & 1 & 1 & & 2 \\
\hline Chaabane et al., 2011a & 1 & 1 & & 2 \\
\hline Chaabane et al., 2011b & 1 & 1 & & 2 \\
\hline Abdallah et al., 2012 & 1 & 4 & 1 & 6 \\
\hline Achillas et al., 2012 & 1 & 2 & & 3 \\
\hline Akgul et al., 2012 & 1 & 1 & & 2 \\
\hline Bostel et al., 2012 & 1 & 1 & & 2 \\
\hline Chaabane et al., 2012 & 1 & 1 & & 2 \\
\hline Elhedhli and Merrick, 2012 & 1 & 1 & & 2 \\
\hline Eskandarpour et al., 2012 & 2 & 2 & & 4 \\
\hline Giarola et al., 2012 & 1 & 1 & & 2 \\
\hline Jamshidi et al., 2012 & 1 & 1 & & 2 \\
\hline Mallidis et al., 2012 & 1 & 2 & & 3 \\
\hline
\end{tabular}

Table 1 (2) . Literature classification according to sustainable development issues. 


\begin{tabular}{|c|c|c|c|c|}
\hline Reference & Economic issues & Environmental issues & Social issues & Total issues \\
\hline Paksoy et al., 2012 & 1 & 2 & & 3 \\
\hline Pérez-Fortes et al., 2012 & 1 & 4 & 2 & 7 \\
\hline Pishvaee et Razmi, 2012 & 1 & 2 & 1 & 4 \\
\hline Sabio et al., 2012 & 1 & 4 & 1 & 6 \\
\hline Shaw et al., 2012 & 3 & 1 & & 4 \\
\hline Shiue and Lin, 2012 & 1 & 1 & & 2 \\
\hline Tekiner-Mogulkoc et al., 2012 & 1 & 2 & & 3 \\
\hline Pishvaee et al., 2012 & 1 & 1 & 2 & 4 \\
\hline Amin and Zhang, 2012a & 1 & 2 & & 3 \\
\hline Amin and Zhang, 2012b & 3 & 2 & & 5 \\
\hline
\end{tabular}

Table 1 (3) . Literature classification according to sustainable development issues.

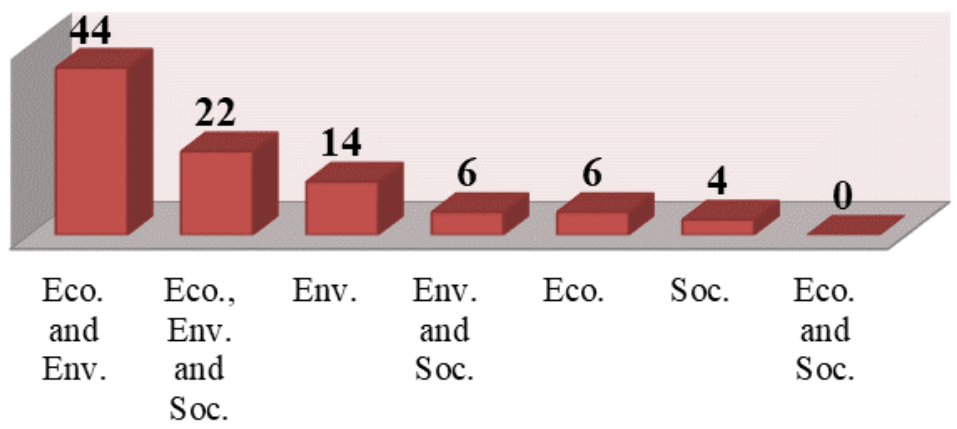

Fig. 1. Literature contributions by sustainable development dimensions in the ninety-six analyzed articles

Our analysis of these ninety-six contributions in relation to sustainable development in supply chains highlights fourteen main issues to comprehensively characterize sustainable performances of supply chain:

\begin{tabular}{llllll}
\hline & Economic issues & & Environmental issues & & \multicolumn{2}{c}{ Social issues } \\
\hline 1. & Reliability & & & 1. & Labor rights \\
2. & Reactivity & 1. & Environment management & 2. & Work conditions \\
3. & Flexibility & 2. & Resources use & 3. & Health and security \\
4. & Quality & 3. & Pollution & 4. & Social commitment \\
5. Financial performance & 4. & Hazardous Materials & 5. & Consumers \\
\hline
\end{tabular}

Table 2 . Main issues which characterize supply chain global performance

\section{CONCLUSION}

Integrating sustainable development principles in supply chain management is, however, a difficult responsibility. Indeed, many companies have very little knowledge and tools in this area, and consulting firms are often disarmed against demands of companies which want to engage in a CSR approach. On research side, although several works have appeared in the literature in recent years, so far there are very few contributions that have addressed sustainable development with a truly integrated vision, taking into account the three dimensions of this latter: economic, environmental and social.

In addition to economic issues, supply chain must consider sustainability issues in design, supply, production, storage, distribution, return flow management, ... this is known as global performance, including economic, environmental and social performances. It is therefore necessary to evaluate this performance qualitatively and quantitatively.

Global performance is a multidimensional concept difficult to measure technically. In fact, evaluation mechanisms currently used by companies to measure progress made through their CSR initiatives do not provide satisfactory answers. Now, challenge for companies is to measure interactions between different global performance dimensions (economic, environmental and social).

Indeed, this literature review confirms the importance of sustainable development applied in supply chain management and highlights fourteen sustainable issues which can characterize supply chain global performance. 


\section{REFERENCES}

Abdallah T., Farhat A., Diabat A. et Kennedyt S., 2012. Green supply chains with carbon trading and environmental sourcing: Formulation and life cycle assessment. Applied Mathematical Modelling. 36, p. 4271-4285.

Achillas C., Aidonis D., Vlachokostas Ch., Moussiopoulos N., Banias G. et Triantafillou D., 2012. A multi-objective decisionmaking model to select waste electrical and electronic equipment transportation media. Resources, Conservation and Recycling. 66, p. 76-84.

Akgul O., Shah N. et Papageorgiou L.G., 2012. An optimisation framework for a hybrid first/second generation bioethanol supply chain. Computers and Chemical Engineering. 42, p. 101-114.

Amin S.H. et Zhang G., 2012a. A multi-objective facility location model for closed-loop supply chain network under uncertain demand and return. Applied Mathematical Modelling. 37(6), p. 4165-4176.

Amin S.H. et Zhang G., 2012b. An integrated model for closedloop supply chain configuration and supplier selection: Multiobjective approach. Expert Systems with Applications. 39, p. 6782-6791.

Azapagic A. et Perdan S., 2000. Indicators of Sustainable Development for Industry: A General Framework. Process Safety and Environmental Protection, 78(4), 243-261.

Azzone G., Masella C. et Bertelè U., 1991. Design of performance measures for time-based companies. International Journal of Operations \& Production Management, 11(3), 77-85.

Barbiroli G. et Raggi A., 2003. A method for evaluating the overall technical and economic performance of environmental innovations in production cycles. Journal of Cleaner Production, 11(4), 365-374

Baret P. 2006. L'évaluation contingente de la Performance Globale des Entreprises : Une méthode pour fonder un management sociétalement responsable ?. 2ème journée de recherche du CEROS, pp. 1-24.

Bojarski A.D., Laínez J.M., Espuna A. et Puigjaner L., 2009. Incorporating environmental impacts and regulations in a holistic supply chains modeling: An LCA approach. Computers and Chemical Engineering, 33, p. 1747-1759.

Bostel N., Dejax P. et Sawadogo M., 2012. A modeling framework for procurement of a retail distribution system with economic and environmental goals. 9th International Conference on Modeling Optimization and Simulation. June 6-8, Bordeaux, France.

Bouzembrak Y., Allaoui H., Masson E., Bouchriha H. et Baklouti M., 2010. Sustainable multimodal supply chain design for recycling waterways sediments. 8th International Conference of Modeling and Simulation (MOSIM'10). 10-12 Mai, Hammamet, Tunisia.

Bradley P., 1996. A Performance Measurement Approach to the Re-engineering of Manufacturing Enterprises. Ireland: University College Galway.
C.M. Tam, Tam V.W. et Tsui W.S., 2004. Green construction assessment for environmental management in the construction industry of Hong Kong. International Journal of Project Management, 22(7), 563-571.

Capron M., Quairel-Lanoizelee F., 2005. Evaluer les stratégies de développement durable des entreprises : l'utopie mobilisatrice de la performance globale. Journée Développement Durable- AIMS - IAE d'Aix-en-Provence, pp.1-22.

Capron M., Quairel-Lanoizelee F., 2007. La responsabilité sociale d'entreprise. Editions La Découverte, Collection Repères, Paris, 122 p.

Carter, C.R. et Ellram, L., 1998. Reverse logistics: A review of the literature and framework for future investigation. Journal of Business Logistics, 19(1), 85-102.

Carter, C.R. et Jennings, M.M., 2002. Logistics social responsibility: An integrative framework. Journal of Business Logistics, 23(1), 145-178.

Castka, P. et Balzarova, M., 2008. ISO 26000 and supply chains-On the diffusion of the social responsibility standard. International Journal of Production Economics, 111(2), 274286.

Chaabane, A., Ramudhin A. et Paquet, M., 2011a. Designing supply chains with sustainability considerations. Production Planning and Control Journal, 22, p. 727-741.

Chaabane, A., Ramudhin A., Kharoune M. et M. Paquet 2011b. Trade-off model for carbon market sensitive sustainable supply chain network design. International Journal of Operational Research, 10, p. 416-441.

Chaabane, A., Ramudhin A. et Paquet, M. 2012. Design of sustainable supply chains under the emission trading scheme. International Journal of Production Economics, 135. p. 37-49.

COM 136, 2006. Mise en oeuvre du partenariat pour la croissance et l'emploi: faire de l'Europe un pôle d'excellence en matière de responsabilité sociale des entreprises. Communication de la Commission au Parlement européen, au Conseil et au Comité économique et social européen, Bruxelles.

COM 366, 2001. Livre vert - Promouvoir un cadre européen pour la responsabilité sociale des entreprises. Commission européenne, Bruxelles.

Corsano G., Vecchietti A.R. et Montagna J.M., 2011. Optimal design for sustainable bioethanol supply chain considering detailed plant performance model. Computers and Chemical Engineering, 35, p. 1384 - 1398.

Darnall N., Jolley J. et Handfield R., 2006. Environmental management systems and green supply chain management: Complements for sustainability? Business Strategy and the Environment, 17, 30-45.

de Benedetto L. et Klemes J., 2009. The Environmental Performance Strategy Map: an integrated LCA approach to support the strategic decision-making process. Journal of Cleaner Production, 17(10), 900-906. 
Dotoli M., Fanti M.P., Meloni C. et Zhou M.C., 2005. A Multilevel approach for network design of integrated supply chains. International Journal of Production Economics. 43(20). p. 42674287.

Dotoli M., Fanti M.P., Meloni C. et Zhou M.C., 2006. Design and optimization of integrated e-supply chain for agile and environmentally conscious manufacturing. IEEE Transactions on Systems, Man and Cybernetics, Part A: Systems and Humans, 36(1). p. 62-75.

Elhedhli S. et Merrick R. 2012. Green supply chain network design to reduce carbon emissions. Transportation Research Part, D. 17, p. 370-379.

Eskandarpour M., Zegordi S.H., et Nikbakhsh E., 2012. A parallel variable neighborhood search for the multi-objective sustainable post-sales network design problem. International Journal of Production Economics, http://dx. doi.org/10.1016/j.ijpe.2012.10.013.

Färe R., Grosskopf S. et Hernandez-Sancho F., 2004. Environmental performance: an index number approach. Resource and Energy Economics, 26(4), 343-352.

Ferreti I., Zanoni S., Zavanella L. et Diana A. 2007. Greening the aluminium supply chain. International Journal of Production Economics. 108, p. 236-245.

Fitzgerald, L. et al., 1992. Performance Measurement in Service Business, 126 p. London: CIMA Publishing.

Fonseca M.C., García-Sánchez A., Ortega-Mier M. et Saldanhada-Gama F., 2010. A stochastic bi-objective location model for strategic reverse logistics. Top. 18, p. 158-184.

Gauthier, C., 2005. Measuring Corporate Social and Environmental Performance: The Extended Life-Cycle Assessment. Journal of Business Ethics, 59(1-2), 199-206.

Germain C., Trébucq S. 2004. La performance globale de l'entreprise et son pilotage : quelques réflexions. Semaine sociale Lamy, pp. 35-41.

Giannikos I., 1998. A multiobjective programming model for locating treatment sites and routing hazardous wastes. European Journal of Operation Research. 104, p. 330-342.

Giarola S., Shah S. et Bezzo F. 2012. A comprehensive approach to the design of ethanol supply chains including carbon trading effects. Bioresource Technology, 107, p. 175185 .

Guillén Gosálbez G. et Grossmann I.E. 2009. Optimal design and planning of sustainable chemical supply chains under uncertainty. AIChe Journal, 55(1), p. 99-121.

Guillén Gosálbez G. et Grossmann I. 2010. A global optimization strategy for the environmentally conscious design of chemical supply chains under uncertainty in the damage assessment model. Computers and Chemical Engineering, 34, p. 42-58.

Gunasekaran A., Patel C. et Tirtiroglu E., 2001. Performance measures and metrics in a supply chain environment. International Journal of Operations \& Production Management, 21(1), 71-87.
Haddach A., Ammari M., Ben Allal L., AZAAR K.and Laglaoui A., 2017. How to measure sustainability of supply chain. International Journal of Advanced Research, 5(5), 401418 .

Halberg N., 1999. Indicators of resource use and environmental impact for use in a decision aid for Danish livestock farmers. Agriculture, Ecosystems \& Environment, 76(1), 17-30.

Henri J. et Journeault M., 2008. Environmental performance indicators: An empirical study of Canadian manufacturing firms. Journal of Environmental Management, 87(1), 165-176.

Hermann B., Kroeze C. et Jawjit, W., 2007. Assessing environmental performance by combining life cycle assessment, multi-criteria analysis and environmental performance indicators. Journal of Cleaner Production, 15(18), 1787-1796.

Herva M. et al., 2008. An approach for the application of the Ecological Footprint as environmental indicator in the textile sector. Journal of Hazardous Materials, 156(1-3), 478-487.

Hugo A. et Pistikopoulos E., 2005. Environmentally conscious long-range planning and design of supply chain networks. Journal of Cleaner Production, 13(15), 1471-1491.

Hugo A., Rutter P., Pistikopoulos S., Amorelli A. et Zoia G., 2005. Hydrogen infrastructure strategic planning using multiobjective optimization. International Journal of Hydrogen Energy, 30, p. 1523-1534.

Hutchins M.J. et Sutherland J.W., 2008. An exploration of measures of social sustainability and their application to supply chain decisions. Journal of Cleaner Production, 16(15), 16881698 .

Jamshidi R., Fatemi Ghomi S.M.T. et Karimi B. 2012. Multiobjective green supply chain optimization with a new hybrid memetic algorithm using the Taguchi method. Scientia Iranica, Transactions E: Industrial Engineering, doi:10.1016/j.scient.2012.07.002.

Jash C., 2000. Environmental performance evaluation and indicators. Journal of Cleaner Production, 8(1), 79-88.

Jung E., Kim J. et Rhee S., 2001. The measurement of corporate environmental performance and its application to the analysis of efficiency in oil industry. Journal of Cleaner Production, 9(6), 551-563.

Kainuma Y. et Tawara N., 2006. A multiple attribute utility theory approach to lean and green supply chain management. International Journal of Production Economics, 10(1), 99-108.

Khan F. I., Sadiq R. et Veitch B., 2004. Life cycle iNdeX $(\mathrm{LInX})$ : a new indexing procedure for process and product design and decision -making. Journal of Cleaner Production, Vol. 12, Issue 1, 59-76.

Krajnc D. et Glavic P., 2003. Indicators of sustainable production. Clean Technologies and Environmental Policy, 5(34), 279-288.

Krajnc D. et Glavic P., 2005a. A model for integrated assessment of sustainable development. Resources, Conservation and Recycling, 43(2), p. 189-208. 
Krajnc D. et Glavic P., 2005b. How to compare companies on relevant dimensions of sustainability. Ecological Economics, 55(4), 551-563.

Krikke H., Bloemhof-Ruwaard J. et Van Wassenhove L.N. 2003. Concurrent product and closed-loop supply chain design with an application to refrigerators. International Journal of Production Research, 41(16), p. 3689-3719.

Labuschagne C., Brent A.C. et Erck Van R.P.G., 2005. Assessing the sustainability performances of industries. Journal of Cleaner Production, 13(4), 373-385.

Labuschagne C. et Brent A.C., 2006. Social Indicators for Sustainable Project and Technology Life Cycle Management in the Process Industry. The International Journal of Life Cycle Assessment, 11(1).

Lamberton, G., 2000. Accounting for sustainable development a case study of city farm. Critical Perspectives on Accounting, $11,583-605$.

Luo Y., Zhou M.C. et Caudill R.J. 2001. An Integrated e-supply chain model for agile and environmentally conscious manufacturing. IEEE/ASME Transactions on Mechatronics, 6(4). p. 377-386.

Lynch R. et Cross K., 1991. Measure Up - the Essential Guide to Measuring Business Performance. 212 p. London: Mandarin.

Mallidis I., Dekker R. et Vlachos D. 2012. The impact of greening on supply chain design and cost: a case for a developing region. Journal of Transport Geography, 22, p. 118128.

Matos S. et Hall J., 2007. Integrating sustainable development in the supply chain: The case of life cycle assessment in oil and gas and agricultural biotechnology. Journal of Operations Management, 25 (6), 1083-1102.

Maxime D., Marcotte M. et Arcand Y., 2006. Development of eco-efficiency indicators for the Canadian food and beverage industry. Journal of Cleaner Production, 14(6-7), 636-648.

Mele F.D., Guillén Gosálbez G. et Jiménez L., 2009. Optimal Planning of Supply Chains for Bioethanol and Sugar Production with Economic and Environmental Concerns. 19th European Symposium on Computer Aided Process Engineering ESCAPE19. Cracow, Poland.

Michelsen O., Magerholm Fet A. et Dahlsrud A., 2006. Ecoefficiency in extended supply chains: A case study of furniture production. Journal of Environmental Management, 79(3), 290297.

Nagurney A., Liub Z. et Woolley T., 2006. Optimal endogenous carbon taxes for electric power supply chains with power plants. Mathematical and Computer Modelling, 44, p. 899-916.

Nagurney A. et Nagurney L.S., 2010. Sustainable supply chain network design: a multicriteria perspective. International Journal of Sustainable Engineering, 3(3), p. 189-197.

Nawrocka D. et Parker T., 2009. Finding the connection: environmental management systems and environmental performance. Journal of Cleaner Production, 17(6), 601-607.
Nema A.K. et Gupta S.K., 1999. Optimization of regional hazardous waste management systems: an improved formulation. Waste Management, 19, p. 441-451.

Noci G., 1997. Designing 'green' vendor rating systems for the assessment of a supplier's environmental performance. European Journal of Purchasing and Supply Management, 3(2), 103-114.

O'Connor M. et Spangenberg J.H., 2008. A methodology for CSR reporting: assuring a representative diversity of indicators across stakeholders, scales, sites and performance issues. Journal of Cleaner Production, 16 (13), 1399-1415.

Olsthoorn X. et al., 2001. Environmental indicators for business: a review of the literature and standardisation methods. Journal of Cleaner Production, 9(5), 453-463.

Paksoy T., Pehlivan N.Y. et Özceylan E., 2012. Fuzzy MultiObjective Optimization of a Green Supply Chain Network with Risk Management that Includes Environmental Hazards. Human and Ecological Risk Assessment: An International Journal, 18(5), p. 1120 - 1151.

Pati R.K., Vrat P. et Kumarc P. 2008. A goal programming model for paper recycling system. Omega, 36, p. 405-417.

Pérez-Fortes M., et al., 2012. Design of regional and sustainable bio-based networks for electricity generation using a multiobjective MILP approach. Energy, 44, p. 79-95.

Pinto-Varela T., Barbosa-Póvoa A.P.F.D. et Novais A.Q., 2011. Bi-objective optimization approach to the design and planning of supply chains: Economic versus environmental performances. Computers and Chemical Engineering, 35, p. 1454-1468.

Pishvaee M.S. et Razmi J., 2012. Environmental supply chain network design using multi-objective fuzzy mathematical programming. Applied Mathematical Modelling, 36, p. 3433 3446.

Pishvaee M.S., Razmi J. et Torabi S.A., 2012. Robust possibilistic programming for socially responsible supply chain network design: A new approach. Fuzzy Sets and Systems, 206, p. 1 - 20.

Pourmohammadi, H., Rahimi M. et Dessouky M., 2008. Sustainable Reverse Logistics for Distribution of Industrial Waste/Byproducts: A Joint Optimization of Operation and Environmental Costs. Supply Chain Forum: An International Journal, 9, p. 2 - 17

Pozo C., Ruiz-Femenia R., Caballero J., Guillèn-Gosalbez G. et Jimenez L., 2012. On the use of Principal Component Analysis for reducing the number of environmental objectives in multiobjective optimization: Application to the design of chemical supply chains. Chemical Engineering Science, 69(1), 146-158.

Quariguasi F.N.J., Bloemhof J.M., Van Nunen J.A.E.E. et Van Heck E., 2008. Designing and evaluating sustainable logistics network. International Journal of Production Economics, 111, p. 195-208.

Ranganathan J., 1998. Sustainability rulers: Measuring Corporate Environmental \& Social Performance. 12 p. Washington: World Resources Institute. 
Rao P. et al., 2006. Environmental indicators for small and medium enterprises in the Philippines: An empirical research. Journal of Cleaner Production, 14(5), 505-515.

Reynaud E., 2003. Développement durable et entreprise : vers une relation symbiotique. Journée AIMS, Atelier développement durable, ESSCA Angers, pp. 1-15.

Sabio N. et al., 2012. Holistic minimization of the life cycle environmental impact of hydrogen infrastructures using multiobjective optimization and principal component analysis. International Journal of hydrogen energy, 37, p. 5385-5405.

Santos d. S. R. et Gonçalves A. F., 2009. An integrated methodology for environmental impacts and costs evaluation in industrial processes. Journal of Cleaner Production, 17(15), 1339-1350.

Shaw K., Yadav S.S. et Thakur L.S., 2012. Supplier selection using fuzzy AHP and fuzzy multi-objective linear programming for developing low carbon supply chain. Expert Systems with Applications, 39, p. 8182 - 8192.

Shiue Y. et Lin C., 2012. Applying analytic network process to evaluate the optimal recycling strategy in upstream of solar energy industry. Energy and Buildings, 54, p. 266 - 277.

Subramanian R., Talbot B. et Gupta S., 2010. An Approach to Integrating Environmental Considerations Within Managerial Decision-Making. Journal of Industrial Ecology, 14, p. 378 398.

Tekiner-Mogulkoc H., Coit D.W. et Felder F.A., 2012. Electric power system generation expansion plans considering the impact of Smart Grid technologies. Electrical Power and Energy Systems, 42, p. 229-239.

Tseng M., Divinagracia L. et Divinagracia R., 2009. Evaluating firm's sustainable production indicators in uncertainty. Computers \& Industrial Engineering, 57(4), 1393-1403.

Vachon S. et Klassen R., 2008. Environmental management and manufacturing performance: The role of collaboration in the supply chain. International Journal of Production Economics, 111(2), 299-315.

Veleva V. et Ellenbecker M., 2001. Indicators of sustainable production: framework and methodology. Journal of Cleaner Production, 9(6), 519-549.

Wang F., Lai X. et Shi N., 2011. Multi-objective optimization for green supply chain network design. Decision Support Systems, 51(2). p. 262-269.

Warhurst A., 2002. Sustainability Indicators and Sustainability Performance Management. 130 p. United Kingdom: World Business Council for Sustainable Development.

You F. et al., 2011. Optimal Design of Sustainable Cellulosic Biofuel Supply Chains: Multiobjective Optimization Coupled with Life Cycle Assessment and Input-Output Analysis. AIChe Journal, 58, p. 1157-1180.

You F. et Wang B., 2011. Life Cycle Optimization of Biomassto-Liquids Supply Chains with Distributed-Centralized Processing Networks. Industrial \& Engineering Chemistry Research, 50, p. 10102-10127.
Zhu Q., Sarkis J. et Lai K., 2007a. Green supply chain management: pressures, practices and performance within the Chinese automobile industry. Journal of Cleaner Production, 15(11-12), 1041-1052.

Zhu Q., Sarkis J. et Lai K., 2007b. Initiatives and outcomes of green supply chain management implementation by Chinese manufacturers. Journal of Environmental Management, 85(1), 179-189.

Zhu Q. et Sarkis J., 2004. Relationships between operational practices and performance among early adopters of green supply chain management practices in Chinese manufacturing enterprises. Journal of Operations Management, 22(3), 265289. 